\title{
The Role of Controlling Credit Sales and Receivables in the Wood Processing Companies of Tuzla Canton, Bosnia and Herzegovina
}

\author{
Emira Kozarević \\ Associate Professor, Faculty of Economics, Univerzitetska 6,75 000 Tuzla, Bosnia and Herzegovina, \\ emira.kozarevic@untz.ba \\ Adisa Delić \\ Full Time Professor, Faculty of Economics, Univerzitetska 6, 75000 Tuzla, Bosnia and Herzegovina, \\ adisa delic.kozarevic@untz.ba \\ Mirzet Omerović \\ Bank officier, Raiffeisen Bank, 15 Maja bb, 75000 Tuzla, Bosnia and Herzegovina, \\ mirzet.omerovic@raiffeisengroup.ba
}

Received (05.12.2018.); Revised (23.01.2019.); Accepted (26.02.2019.)

\begin{abstract}
When companies sell goods/services, they may request cash prior to or at the delivery or they may offer deferred payment. The decision on credit policy is a trade-off between the benefits gained from increased sales and the costs of approving credit. Based on the appropriate analysis of reports, controlling should help the management to bring such business decisions aimed towards customers and to take all the necessary measures for obeying the appropriate legal regulations. This way, controlling may influence better liquidity of a company, which includes faster cash turnover, payment to its suppliers, lower outstanding accounts, and better profitability. Apart from the general importance of controlling credit sales and collection of receivables, the article examines the position and the role of controlling in the companies operating in wood processing as the fastest growing industry in Bosnia and Herzegovina.
\end{abstract}

Keywords: controlling, credit sales and receivables, wood processing companies, Tuzla Canton

\section{PREVIOUS RESEARCH ON CREDIT SALES AND COLLECTION OF RECEIVABLES}

When buying products and services, what customers are most interested in is the possibility for deferred payment, or credit sales. As customers are driven by the time value of money which assumes "a dollar in the present is worth more than a dollar in the future", they see credit sales financing as an important segment of their decision on purchase.

Money is not the purpose of entrepreneurial organization existence but rather the "oxygen" needed to achieve that purpose. In the spirit of the saying "it's better safe than sorry", liquidity and regular collection of receivables are primarily ensured by prevention, timely usage and understanding of available information, as well as organized procedure based on laws and regulations for communication with customers[1].
In the real world, it is unrealistic to expect that customers will always use cash for certain products and services. For the majority of companies, credit sales financing or "investment into receivables" is a regular activity. Individuals or companies that buy on credit actually borrow from suppliers; they save money today and pay later.

From the accountancy perspective, when a customer is approved a credit, accounts receivable occur. Such receivables can include trade credits, if a credit is approved to a company, and consumer credits if a credit is approved to an individual [2].

Receivables are actually the money which customers owe to companies as they bought products and services on credit. It can be stated that receivables are seen as the assets with certain value and as such, they are registered as an important element in company's balance sheet since all business 
performances depend more or less on accounts receivable.

\subsection{Research on accounts receivable}

To completely collect receivables is one of the most difficult tasks in business activities of the companies in Bosnia and Herzegovina (BiH). Default payments are almost a rule, which de facto paved the way to the companies whose only activity is to trade with receivables [1].

The literature, Internet and other available resources provide extremely interesting data related to collection of receivables. It is an almost impossible task to review all the existing research on this topic. Many authors gave their definitions and pointed to their importance.

Collection of receivables is extremely important for every company and it is one of the most sensitive aspects of business, especially in the time of market instability and illiquidity. Due to debtor's late payment, companies (creditors) face difficulties in business activities, business results are lower and companies are unable to pay their obligations in time. Every company faces the lack of payment discipline and the best prevention is to regularly check the solvency and reputation of its business partners and reject doing business with those that experience difficulties in payment. The solvency of the present and future clients is extremely important for the assessment of their financial position as well as for the possibility to collect receivables. Every company needs to list the types and order of the activities, authorizations, and responsibilities of its employees in the procedure of invoicing and charging the products sold and services offered. A decrease in this segment of business activities is made by the establishment of department for controlling credit sales and receivables [3]. Every company that provides deferred payment or credit sales needs to have a clearly defined plan of collection of its receivables.

\subsection{Research on credit sales}

Credit sales or investment in receivables is a regular activity for the majority of companies. Every sale that is not immediately accompanied with payment results in receivables orcustomer's obligation to make the payment in some future period. Since all the activities planned to happen in the future are more or less risky, the approval of credit sales is linked to a certain amount of risk. Controlling holds a special position in planning and supervision of credits sales but also in developing standards used in the realization of such a process. Furthermore, receivables hold an important position in the structure of company's assets and its liquid assets. Bearing in mind the strategic and tactical importance of this position in company's balance sheet, all business performances depend on receivables to a lesser or larger degree [4].

Credit sales are a regular practice and they take as many as 75 percent of the total sale, which is why they require strict collection program. However, only 85 percent of due receivables are collected within 30 days. Depending on the company, as many as 3 to 11 percent is not collected within 180 days. The need for a fast action is evident.

This can be solved by the maturity of the entire amount of the premium in case the client does not respect the agreed day of payment. The creditor company needs to act immediately when receivables become due as the practice shows that the chances of collection decrease as the time after maturity passes [3].

The most important thing to do during the approval of credit to customers is to segment customers. Proper segmenting and targeting are important in planning, defining measures and gauging labor efficiency at all levels and more or less at all business functions (management, sale, finance management, collection, marketing, etc. Segmentation is most often used by means of the SWOT analysis.

\subsection{Previous research on the effect of credit sales and collection of receivables on company's liquidity/profitability}

Credit sales are determined by sales and profit goals of the company. Sales goals cannot be achieved without the assumption that the company would run its business activities with credit sales. Company's liquidity, apart from other things, depends on the dynamics and quality of collection of receivables or their conversion into money. Company's profit goals are conditioned by the quality of the achieved business results and the scope of employed resources on the one hand but cannot be achieved unless sales goals are achieved.

Company's growth and development are achieved through the increase in products and services and the sustainability of such development is measured by means of several parameters among which liquidity is one of the most important. Poor liquidity as a consequence of the lack of payment discipline affects the entire company as all market participants enter "vicious circles" of the lack of payment. 
In order to reduce and minimize credit sales risk, the sales company uses the controlling of credit sales and receivables. Controlling holds a special position in planning and supervision of credits sales but also in developing standards used in the realization of such a process [5].

Company's controlling department is responsible for the creation and revision of credit sales policy as well as credit standards that should be written in the appropriate format. As such, they need to provide clear guidelines in terms of company's activities in the process of approving credits sales in every specific case.

The biggest "disease" of modern companies are outstanding receivables. This is a phenomenon that spread with lightning speed and nowadays leads many companies to bankruptcy. The most serious problems lies in the fact that most companies hold the companies that need to pay responsible for such situations although business practice indicates that receivables are the consequence of bad sale.

Receivables are the component of every company's assets. They are the result of numerous factors with the most important one being our decision to sell our goods or services with the belief that customers will pay them in the future. This is precisely the characteristic by which they are just like any other form of assets that organizations and employees invest in [6].

A direct effect of credit sales and collection of receivables on company's liquidity and profitability have not so far been presented. It is rather difficult to discuss their effect on company's profitability and even more difficult when it comes to company's liquidity. Bearing in mind the definitions of liquidity and profitability as well as present research into this subject matter, it can be stated that money is not the essence of business but it is the key resource that keeps the company alive. Under the conditions of the global economic crisis and the general illiquidity, the focus must be on the collection and liquidity (company's safety and survival). In order to improve company's safety, profitability can be "sacrificed" in the short run and by using favorable prices and other commercial requirements (such as deadlines) customers can be motivated to regularly pay and issue high quality guarantees. In the long run, faster and more extensive income coming from the collection of receivables with less resources used (assets, people, and most importantly time) decreases the cost of doubtful claims, compensates for short term sacrifice, and improves profitability.
Every sales manager needs to regularly monitor certain indicators so as to manage sales processes and lead the company to good results. Managers can actually notice trends and directions of sales movements rather simply - they only need to monitor some important relations.

One of the basic and very significant company's indicators is the ratio between its receivables and liabilities to suppliers. If we sell our products in the period longer than the one when we purchase them (meaning that the receivables turnover ratio is lower that the debt turnover ratio), we put the company in danger of illiquidity. In order to avoid illiquidity, we must pay our liabilities from our own capital (invested in the company or earned in the past) rather than from the money we got from our customers. Such practice is wrong since the capital we earned in the past should be invested in company's development and expansion rather than paying debts. One of the ways to pay our suppliers is to borrow money (from a bank for example) and pay interest [7].

\section{RESEARCH METHODOLOGY}

The empirical research was conducted based on application of scientific methods of internal and external research. The internal desk research was used for processing secondary sources of data and information while the external or field research was used for collecting data by a survey. The main instrument for data collection was a questionnaire. The target subjects were the wood processing companies in Tuzla Canton, $\mathrm{B}$ i $\mathrm{H}$.

Data collection was executed based on the proportionally stratified sample, since it belongs to the category of random samples and enables the assessment of reliability when it comes to making conclusions on the studied parameters.

The empirical research included 50 subjects that were selected based on their availability and willingness to cooperate.

A total of 75 questionnaires were distributed with 50 questionnaires appropriately filled in. This means that the return rate was relatively high (66.67\%).

While the companies were selected in the above mentioned strata, a controlled random sampling method was used whereby the coverage of different types of basic products was taken into account, so as to identify the current state of application of controlling in the wood processing companies in Tuzla Canton. 


\section{CONTROLLING CREDIT SALES AND COLLECTION OF RECEIVABLES IN THE WOOD PROCESSING COMPANIES IN TUZLA CANTON}

Different procedures and methods of data collection were used, in accordance to the postulated research questions. Attention was especially paid to descriptive statistical analysis.

\subsection{Descriptive statistical analysis of research indicators}

Descriptive statistical analysis enabled a detailed study of company's belonging to the sample, planning and measuring results, applying credit sales and collection of receivables, and most importantly, applying controlling in the company. Descriptive statistics included the calculation of the arithmetic mean, mode, median, and standard deviation.

\subsubsection{Being part of the sample}

By analyzing the basic products or services offered the by the wood processing companies in Tuzla Canton, we found out that 50 companies in the sample were divided as follows: 13 of them are furniture factories, 11 companies deal with wood processing, seven companies produce joinery, six companies deal with final processing of wood, four companies produce paper, while nine companies offer some other basic product or service and include pellet production, sawmills, band saws, etc.

The organization of the sample companies reveals that the majority of them (49 or $98 \%$ ) are limited liability companies while $2 \%$ are shareholding companies. The analysis of their organization shows balance between centralized and partially centralized organization, while those with decentralized organization into profit segments were not included in the sample.

The analysis of company's complexity included the factors such as several different products and services offered by the company, company's organization units situated at different places and/or the company being a large organization with a complex process of one product/service that can be divided into stages. The results show that $98 \%$ of the companies in the sample are complex companies that mainly offer several different products and services.

\subsubsection{Budgeting and measuring company's results}

Planning and controlling, two different but closely linked functions, depend on each other. Without previous planning, control process does not have its grounding and consequently the same is true for controlling in a company [5]. The research into the extent to which the observed companies prepare multi annual and annual budgets and plans showed some interesting results. It needs to be mentioned that annual and multi annual plans are an important segment in every organization and indicate the company's path and how it should manage its business policies. These plans should be realistic and always aimed towards the realization of company's goals. It can be observed that $96 \%$ of the analyzed companies prepare annual and multi annual business plans while $4 \%$ of them do not. It is evident that the companies have a prepared path to establish controlling departments.

The research also revealed that the majority of the observed companies compare their results with the adopted plans as well as with the results they achieved in previous years. The results show that $68 \%$ of the companies perform such analysis, $24 \%$ of the companies compare their results with their achievements in previous years, while $8 \%$ of the companies compare their results with the adopted plans only. What is interesting is that even the companies without annual and multi annual business plans compare their results with those from previous years.

It is also evident that $96 \%$ of the observed companies have a defined plan related to their customers and collection of receivables whereas $4 \%$ of them do not have such a plan. Table 1 shows the time period for credit sales for 50 companies observed.

Table 1.Time period for credit sales

\begin{tabular}{|l|c|c|}
\hline Time period & Absolute frequencies & Relative frequencies \\
\hline Up to 15 days & 1 & $2 \%$ \\
\hline 15 to 30 days & 13 & $26 \%$ \\
\hline 30 to 45 days & 34 & $68 \%$ \\
\hline Over 45 days & 2 & $4 \%$ \\
\hline Total & 50 & $100 \%$ \\
\hline
\end{tabular}

Table 1 shows that the wood processing companies in Tuzla Canton most often use credit sales for the period of 30 to 45 days to sell their products. This time period is preferred by $68 \%$ of the observed 
companies, $26 \%$ of them prefer the period from 15 to 30 days, $4 \%$ of the companies offer deferred payment for the period longer than 45 days while $2 \%$ opt for the period shorter than 15 days. The data reveal that all the companies basically obey the Law on Financial Business Operations of B i H Federation in terms of the approval of deferred payment. This law specifies the payment deadline within 30 days, unless specified otherwise by the two parties. The deadline may be determined for the period no longer than 60 days [8].

Timely collection of receivables is something that should be important to every company that offers credit sales. The very basis of economy includes selling the product and collecting receivables. The data obtained from the observed companies reveal that $88 \%$ of them see timely collection of receivables as extremely important while $12 \%$ of them see it as extremely important although not of vital importance for company's business activities. None of the observed companies believe that timely collection is without importance.

At this point, bearing in mind the financial problems as the consequence of the economic crisis, nonpayment becomes common. The goal of successful collection is not just to collect the debt but also to build customer's loyalty. Every company strives to keep its customers and several techniques of collection of receivables are used. The basic techniques include [5]:

$>$ oral communication and correspondence with customers,

$>$ application of payment guarantee instruments;

$>$ court, arbitrage, or other procedures of collection of receivables.

The research reveals that the highest number of the observed companies use oral communication and correspondence with customers (36\%). All three techniques mentioned are used by $32 \%$ of the observed companies, $20 \%$ of them use oral communication and correspondence with customers along with the application of payment guarantee instruments, while $12 \%$ of them use some other techniques of collection of receivables.

Some $92 \%$ of the observed companies think that it is appropriate to initiate court procedures against the customers that make late payment. However, they all stated that the company should double check the details regarding that customer as court procedures are usually the ways in which companies lose customers.
3.1.3 Descriptive statistical analysis of application of controlling in the company

Controlling allows for more quality management of future events and provides answers to specific questions - what are the trend values and what can be expected in the future, into which products should we invest more, which products should be canceled, which customers should be avoided, which markets should be developed and which should be abandoned, how to finance, and many other questions related to company's business operations [5]. Controlling is then management philosophy based on economic logic of rationality. It is a set of knowledge needed to use numerous data within and outside the company in order to collect the optimum number of information required by managers to make high quality decisions. The focus of controlling on the future enables companies to face reality more easily when they depart from the specified goals. Controlling investigates whether these goals are met, questions the reasons that brought about divergence and helps companies be back on track. If the road is not the right one, controlling fosters the revision of strategies. In contemporary business practice, controlling plays one of the most important roles in company's functioning.

The data obtained from the survey show some interesting facts. Twenty-three out of 50 observed wood processing companies in Tuzla Canton have the departments for controlling credit sales and receivables. The fact that $46 \%$ of the observed companies use controlling answers the question "Why is the wood processing industry the fastest growing industry in B i $\mathrm{H}$ in the last ten years?" This is even more important as some studies show that only five to ten percent of the companies in all $\mathrm{B} \mathrm{i} \mathrm{H}$ industries use controlling. This leads us to the conclusion that controlling is present in the wood processing industry to a satisfactory level.

If the onset of controlling application in the observed companies is taken into consideration, it is evident that the companies mainly started applying controlling after the year of 2014. The research data show that $30.43 \%$ of the companies introduced controlling into their business operations in 2016, $26.09 \%$ of them introduced it in 2015 , while the same percentage $(13.04 \%)$ of the companies introduced it in 2010 and 2017 . Some $8.7 \%$ of the companies formed their controlling departments in 2014, while $4.35 \%$ of them did that in both 2011 and 2013. The data indicate that $69.56 \%$ of the observed companies introduced controlling in their business operations after 2014. 
The research shows that since the year when controlling departments were formed, the observed companies experienced significant increase in income, which points to the fact that the application of controlling improved company's business activities. In addition, all the companies stated that the establishment of these departments reduced outstanding receivables as well as the costs of credit sales and collection of receivables. This consequently led to shorter periods of late payment by customers. The research results allow us to conclude that the establishment of controlling departments resulted in higher profit for the companies. Controlling credit sales and receivables reduces business costs and enables everybody in the company to perform their tasks more efficiently. Companies become more competitive in the market and increase the level of their services. Apart from the benefits of controlling, there should be some slight changes made in the observed companies so that controlling could fully take root. The observed companies confirmed their satisfaction with the application of controlling and recommended that all the companies should establish such department so as to be more efficient in their tasks and reach their goals more easily.

\subsection{Comparison of financial reports}

The access to financial reports of the observed companies was more difficult than expected. However, by means of the Banking Information System (BIS) present in all the banks on the territory of $\mathrm{B} \mathrm{i} \mathrm{H}$, we were granted access to financial reports for internal usage with any copying and duplicating prohibited.
The examination of the financial reports revealed that all the companies have roughly the same position in the balance sheets. Using the innovative program prepared in Excel we made the horizontal analysis of balance sheets and income statements of all the observed companies and calculated the following indicators:

$>$ receivables turnover ratio,

$>$ receivables turnover ratioin days,

$>$ due receivables in days,

$>$ write-off receivables ratio.

After the calculations were made, we conducted the statistical analysis and compared the companies that use controlling of credit sales and collection of receivables with the companies that do not have such departments in their business organization.

\subsubsection{Receivables turnover ratio}

The receivables turnover ratio measures the times that receivables invoices are generated and collected during the year. This ratio is calculated by dividing the net value of credit sales during a given period by the average accounts receivable during the same period [9].

By observing the financial reports, we calculated the receivables turnover ratio for every observed company for the previous three years. The results are in the range of 2.29 to 6.87 . The average receivables turnover ratio for the year 2017 is 4.23 . In 2016, the average receivables turnover ratio in the observed companies was 3.62 while in 2015 its average value was 4.01 .

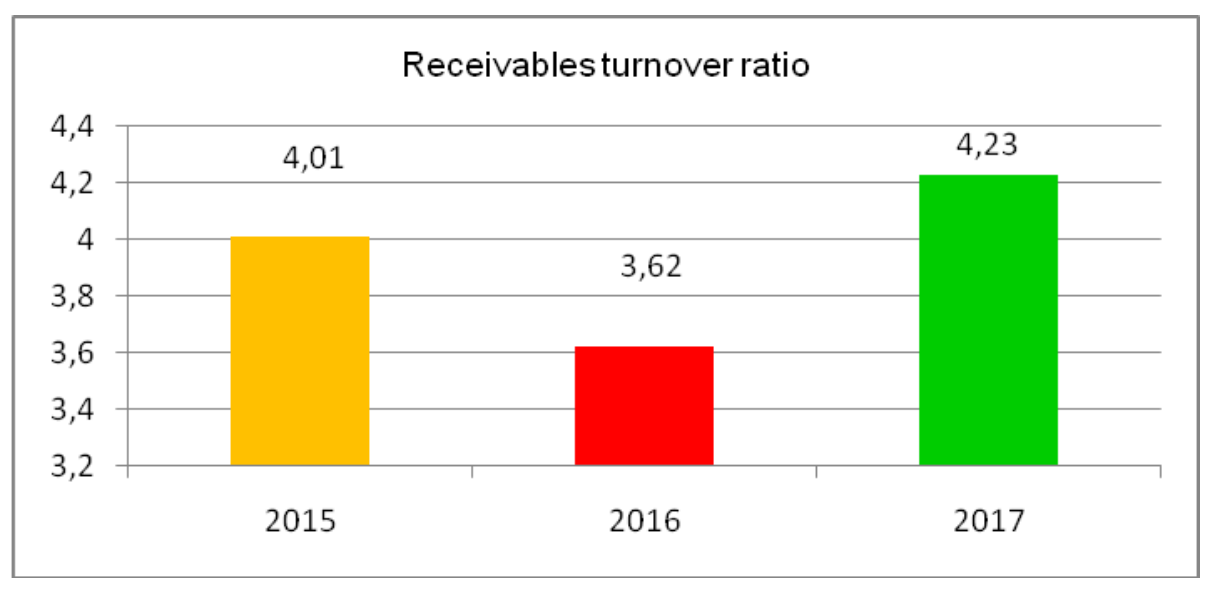

Figure 1. Receivables turnover ratio in the period 2015-2017.

Figure 1 clearly indicates the difference in the average receivables turnover ratio in the years 2015,
2016, and 2017. It is evident that this indicator significantly increased in 2017, when compared to 
2016. Such a ratio implies that the companies were more efficient in managing their receivables in 2017 than in the previous years.

When we compared the companies that use controlling to those that did not establish such departments, we took the year 2017 as the base year. We compared their average receivables turnover ratios. In the companies that established controlling departments, this ratio is in the range between 3.85 and 6.87 , while in the companies that lack such departments, its value ranges from 2.29 to 5.24. The average amount of the receivables turnoverratio in the companies that use controlling for credit sales and receivables is 5.08 while the same indicator in the companies without controlling department is 3.49 .

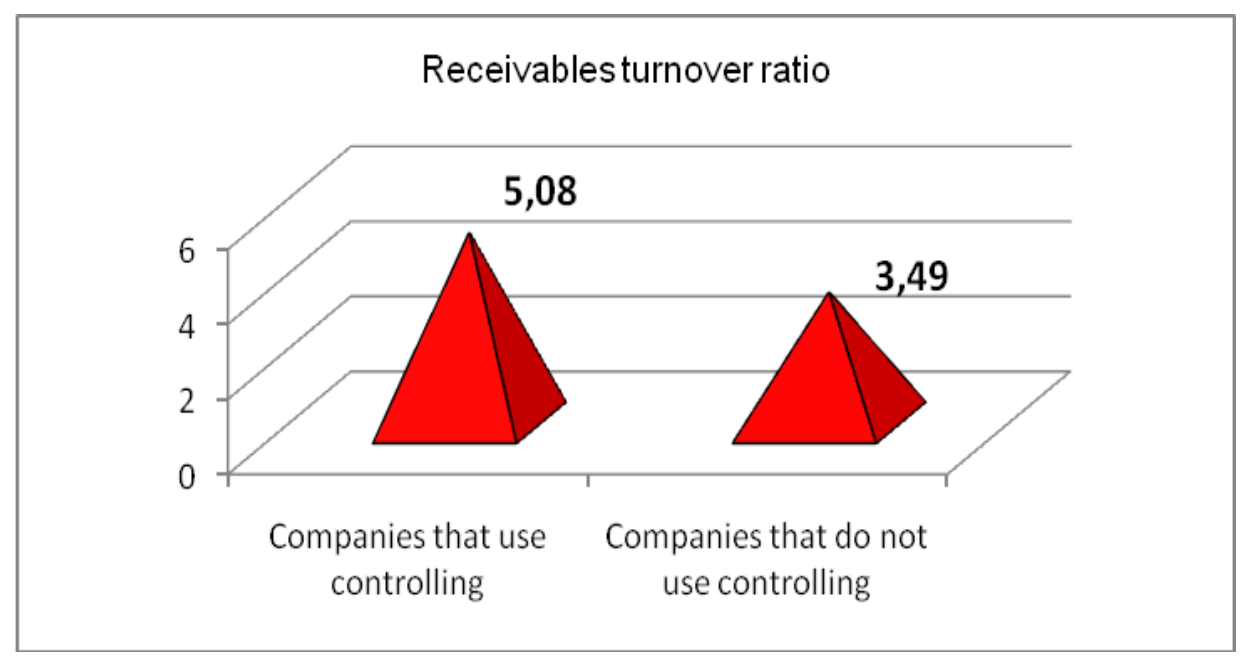

Figure 2. Comparison of the average receivables turnover ratio between the companies that use and those that do not use controlling

The graphic presentation implies that the companies with controlling departments have higher revenues from credit sales and more successful collection of receivables. In addition, the gap between the highest and the lowest ratio values indicates that the companies that use controlling in their business activities have a far better policy of collecting receivables than those companies that do not use controlling.

\subsubsection{Receivables turnover ratio (days)}

This is yet another important ratio which shows the difference between the companies that use controlling and those that do not have such departments. As evident from its name, the ratio measures how many days per year are averagely needed by a company to collect its receivables and turn them into cash. If the collection period exceeds company's credit terms, it might be a signal that the company is inefficient in collecting revenues from credit sales or that it approves credit to margin customers [9].

The receivables turnover ratio (days) in the observed companies ranges from 53.13 to 159.39 days. Here again, we took the year 2017 as the base year. The research shows that the average receivables turnover is 93.29 days, which exerts pressure on short term liquidity of these companies and may point to excessive losses due to doubtful claims. The average value of this ratio for the companies that use controlling is 74.13 days while its value for the companies that do not use controlling is 109.75 days. When the years 2015 and 2016 are taken into consideration, we conclude that the average period of receivables collection decreased. In 2016, the average value of this ratio was 86.23 days for the companies with controlling departments and 134.20 for those without these departments. However, in the current period, the time of collection of receivables was shortened. This indicator sees a positive trend but controlling departments shall insist on the provision of the rationale for the changes since there is no uniform interpretation of the changes of this as well as other indicators.

\subsubsection{Days sales outstanding}

Days sales outstanding is a measure which can be generated from the receivables turnover ratio and is applied by customer categories. If we sum up all accounts receivable from the customers within one category of payment terms, calculate the average receivables turnover in days and subtract the number of days for deferred payment, the result will be the average number of days sales outstanding within that category [9]. 


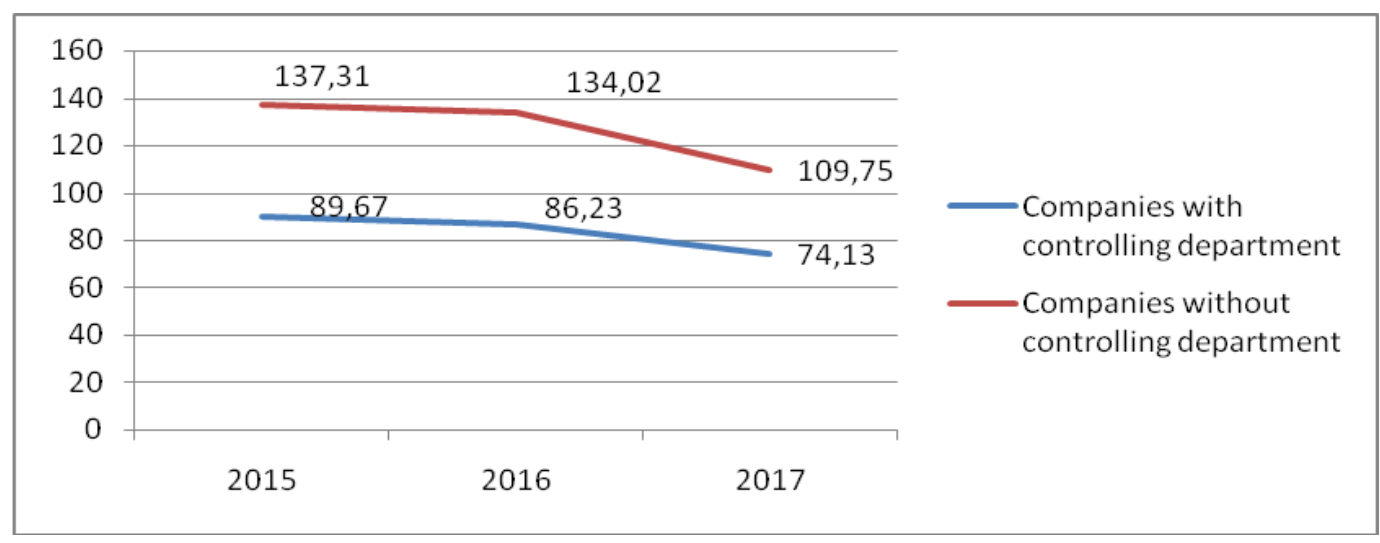

Figure 3. Accounts receivable ratio (days) - trend for the period 2015-2017

While calculating the days sales outstanding, we took the data on the number of days approved for deferred payment which were obtained from the questionnaire. The calculation and addition of all average days sales outstanding lead us to an interesting fact - the customers in the observed companies were late in payment for 32.05 days on average (the data for 2017). If the years 2016 and 2015 are taken into consideration, when the customers were late in payment for 46.27 and 36.86 days respectively, we can conclude that late payments are rather reduced.

The tendency of reduction in late payment and outstanding receivables goes hand in hand with the Law on Financial Operations which specified criminal provisions for customers that are late in payment. The implementation of this law shall significantly reduce the number of such customers.

\subsubsection{Write-off accounts ratio}

The ratio of write-off accounts is calculated when the total write-off accounts are divided by the total revenue from credit sales. As the majority of indicators of interest for controlling, this ratio assumes special importance when its trend is observed.
We observed the trend of the write-off accounts ratio. We first calculated the total amounts and the average for every year. In that way we obtained the average ratio of write-off accounts for all 50 observed companies within three last years. Then we calculated the average ratios of write-off accounts for the companies that use controlling of credit sales and collection of receivables as well as for the companies that do not have controlling departments.

The research shows that $1.97 \%$ of the total credit sales value in 2017 was written off. The trend was worrying as from $2.32 \%$ in 2015 the ratio increased to $3.16 \%$ in 2016 . If the average ratio of write-off accounts is observed in the companies with controlling departments, it is evident that the trend developed from $1.99 \%$ in 2015 , over $2.02 \%$ in 2016 , to $1.71 \%$ in 2017 . It is easy to recognize that there were no major oscillations except for the decrease from $2.02 \%$ in 2016 to 1.71 in 2017. What is also evident is the difference between the companies that have controlling departments and those without controlling departments, which in 2016 registered the value of write-off accounts of $4.17 \%$.

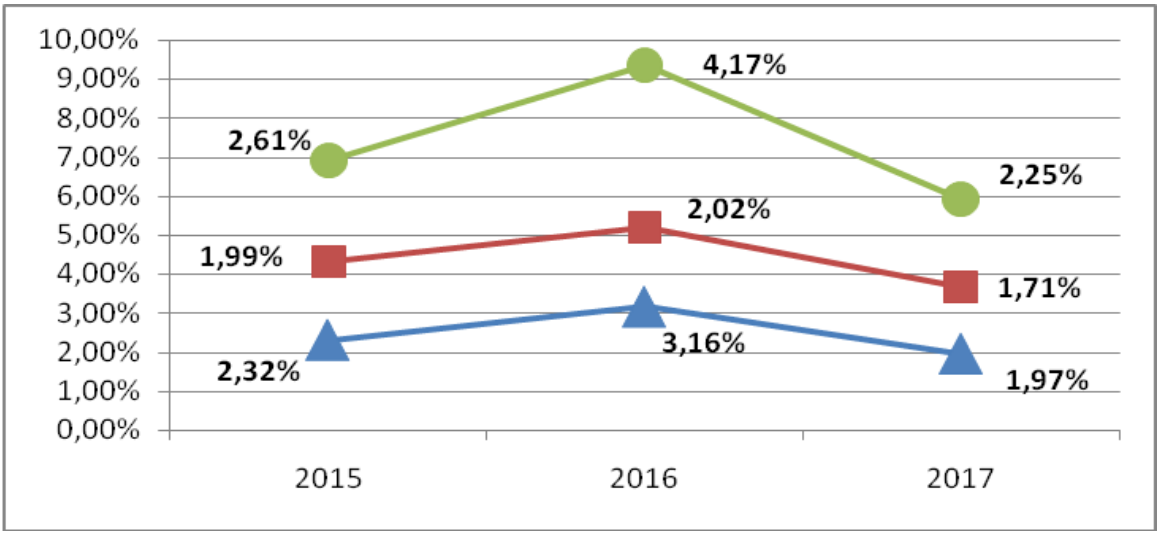

Figure 4. Write-off accounts ratio trend 
Figure 4 shows the trend in percentages. The green colored circles are used for the companies that do not have controlling departments. The red colored squares mark the companies that use controlling in their business activities while the blue colored triangles represent the average trends for all the companies.

The graph leads us to conclude that the introduction of controlling reduces company's write-off receivables. Furthermore, the companies with controlling departments have more rigid policies of collection of receivables and consequently experience less write-offs.

\subsection{Controlling of credit sales and collection of receivables in the wood processing companies in Tuzla Canton}

A total of 142 companies were active in the wood processing industry of Tuzla Canton in 2017. They registered the growth of total revenue and profit compared to two previous years. The fact that export revenue takes $62.23 \%$ of the total revenue at the level of the industry shows that these are mainly export-oriented companies. The main segment of sales activities of these companies is the sale with deferred payment. As in any other sectors, there are problems with the collection of receivables. Customers are very often late in payment or become illiquid in the meantime, which forces companies to write off their receivables.

The wood processing companies in Tuzla Canton largely use controlling of credit sales and collection of receivables. It is interesting that $46 \%$ of these companies have established controlling departments for this purpose, which places them on the top and potentially indicates that the wood processing industry is the most developed sector in $\mathrm{BiH}$. The companies that established controlling departments are much more successful in managing their receivables. They also pay more attention to approving deferred payment by means of customer classification.

The significance of controlling departments is evident in the results achieved in collection of receivables by the companies that established these departments. The analysis of the most important ratios related to controlling credit sales and collection of receivables showed that the companies that use controlling have much better indicators:

- $\quad$ higher receivables turnover ratio;

- lower receivables turnover in days;

- less days sales outstanding;

- lower write-off accounts ratio.

Besides, it should be emphasized that controlling credit sales and collection of receivables is an ideal mechanism for increasing company's profit and a very good mechanism for reducing doubtful claims [10].In addition, controlling can be a remedy for the companies filing for bankruptcy. It is known that companies often face bankruptcy due to a bad policy of collection of receivables and excessive write-offs and controlling departments may reduce the risk of bankruptcy. By using controlling, some wood processing companies in Tuzla Canton successfully fight bankruptcy and made significant success in the previous period. The costs of business and financing operations in the companies that established controlling of credit sales and collection of receivables are significantly lower as companies rely on the resources obtained through collection processes. In addition, these companies do not have to reach for third parties or institutions that collect receivables. The companies also reduce their court expenses as they often succumb to pressure and can only recover claims in court, which is why they lose their customers.

Controlling credit sales and collection of receivables provides numerous benefits for the companies, which is presented in the following diagram:

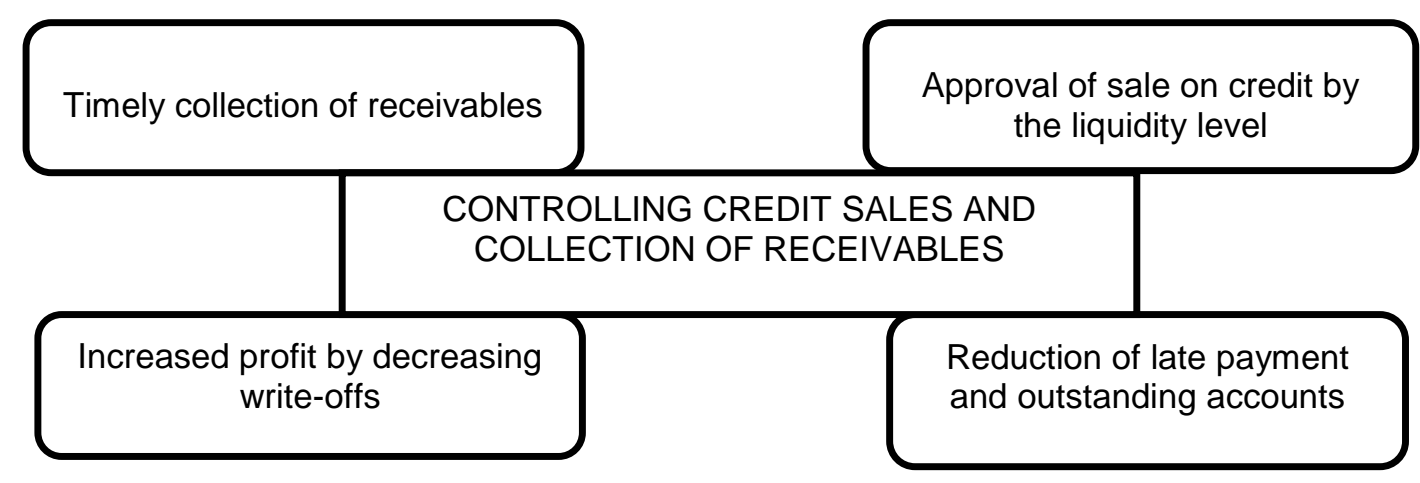

Figure 5. Benefits of controlling credit sales and collection of receivables 
Introduction of controlling credit sales and collection of receivables requires the staff to adapt to organizational changes, which results in constant improvement of company's business activities. Naturally, resistance to change may occur, which is a normal human reaction. The reasons for resistance are numerous: lack of knowledge, skills or abilities, fear of losing the current position in the organization, fear of getting fired, etc. In order to eliminate the aversion towards the introduction of controlling credit sales and collection of receivables, we recommend that the wood processing companies constantly organize seminars on this topic and consult the companies that have already established controlling departments.

\section{CONCLUSION}

Based on the above information, a general conclusion can be made that the research examined and identified the relevant theoretical, methodological, and empirical characteristics of controlling credit sales and collection of receivables. This allowed us to conclude that the establishment of controlling credit sales and collection of receivables will have the function of increasing profitability.

Collection of receivables is extremely important for every company and it is one of the most sensitive aspects of business, especially in the time of market instability and illiquidity. Due to debtor's late payment or lack of payment, companies (creditors) face difficulties in business activities. This brings lower business results and makes them unable to pay their obligations in time. Every company faces the lack of payment discipline and the best prevention is to regularly check the solvency and reputation of its business partners and reject doing business with those that experience difficulties in payment. A decrease in costs of collection of receivables is made by the establishment of controlling departments.

The introduction of controlling credit sales and collection of receivables has lately become a topic of discussion in $\mathrm{B} \mathrm{i} \mathrm{H}$, due to current debt crises and the adoption of the Law on Financial Operations. Controlling is a key issue for a more extensive growth of the wood processing industry, as the fastest growing industry in $\mathrm{B} \mathrm{i} \mathrm{H}$, since the current systems of collection of receivables are outdated and their application results in various problems. These problems stem from the fact that the pre-war system has not properly developed into the post-war system which abounds in turbulence and unforeseen situations. With all this said, the need is emphasized for the development of stabile foundations for the controlling of credit sales and collection of receivables. Such development would focus on a fast growing industry such wood processing and on adaptation to changes, which would set the main principles for maintenance and increase of company's profitability.

The empirical research showed that the application of controlling credit sales and collection of receivables in the wood processing companies regulates collection of receivables and reduces late payments by customers, which might result in constant improvement of business processes and increased profitability.

Finally, it should be stated that the professionalization of staff and establishment of controlling departments for credit sales and collection of receivables is an imperative in the wood processing industry. In order to improve business results, companies need to establish these departments and clearly assign the tasks. In addition, controlling credit sales and collection of receivables is an important mechanism used as a driving force for the companies to escape bankruptcy.

\section{REFERENCES}

[1] Baker, H. K., Power, G.E. (2005), Understanding Financial Management: A Practical Guide, Blackwell Publishing Ltd, Oxford.

[2] Preißler, P. R., Stoffel, K. (2013), Übungs - und Klausrenbüch Controlling: Controlling und Kosten - und Leistungsrechnung,OldenbourgVerlagMünchen.

[3] Andersson, S., Bergman, T. (2009),"Controlling Corruption in the Public Sector", Scandinavian Political Studies, Vol.32, No. 1, pp. 45-70.

[4] Karić, M. (2009),Naplatapotraživanjaodkupaca, The Faculty of Economics, Osijek.

[5] Polić, N., Kozarević, E., Džafić, J. (2016), Finansijskikontroling, The University of Zenica,Zenica.

[6] Khan, M. Y., Jain, P. K., (2008), Financial Management, McGraw-Hill, New Delhi.

[7] Omerhodžić, S. (2010), Analizafinansijskihizvještaja, Harfograf, Tuzla.

[8] Zakon o finansijskomposlovanjuFederacijeBiH, „SlužbenenovineFederacijeBiH“ br. 15/16 [Law on Financial Business Operations of Bosnia and Herzegovina Federation, "Official Gazette of Bosnia and Herzegovina Federation" no. 15/16].

[9] Belak, V. (2014), Analizaposlovneuspješnosti, RRiF, Zagreb.

[10] Ziegenbein, K. (2008), Kontroling, RRiF, Zagreb. 


\title{
Uloga kontrolinga prodaje i potraživanja kredita u drvo-prerađivačkim preduzećima Tuzlanskog kantona, Bosna i Hercegovina
}

\author{
Emira Kozarević, Adisa Delić, Mirzet Omerović
}

Primljen (05.12.2018.); Recenziran (23.01.2019.); Prihvaćen (26.02.2019.)

\begin{abstract}
Abstrakt
Kada kompanije prodaju robu/usluge, one mogu potraživati gotovinu pre ili na isporuci ili mogu ponuditi odloženo plaćanje. Odluka o kreditnoj politici je kompromis između koristi od povećane prodaje i troškova odobravanja kredita. Na osnovu odgovarajuće analize izveštaja, kontroling treba da pomogne menadžmentu da donese takve poslovne odluke usmerene prema kupcima i da preduzme sve potrebne mere za poštovanje odgovarajućih zakonskih propisa. Na taj način, kontroling može uticati na bolju likvidnost preduzeća, što uključuje brži promet gotovinom, plaćanje dobavljačima, manje otvorene račune i bolju profitabilnost. Pored opšte važnosti kontrole prodaje $i$ naplate potraživanja, u članku se razmatra položaj i uloga kontrolinga u preduzećima koja se bave preradom drveta kao najbrže rastućom industrijom u Bosni i Hercegovini.
\end{abstract}

Ključne reči: kontroling, kreditna prodaja i potraživanja, preduzeća za preradu drveta, Tuzlanski kanton 